\title{
Evaluation of the stability of cadmium [Cd] in slags from the Waste Thermal Treatment Plant [WTTP] in Kraków
}

\author{
Beata Kosa-Burda $^{1, *}$, and Alicja Kicińska $^{1}$ \\ ${ }^{1}$ AGH University of Science and Technology, Faculty of Geology, Geophysics and Environmental \\ Protection, Mickiewicza 30 av., 30-056 Kraków, Poland
}

\begin{abstract}
The purpose of the research was to evaluate the mobility of cadmium $[\mathrm{Cd}]$ in slags from municipal waste incineration. The evaluation was based on TVA's two-stage wash-out test on fresh samples and on samples exposed to atmospheric factors' influence for a period of two weeks. The tested slag samples were collected from the municipal Waste Thermal Treatment Plant [WTTP] in Kraków. Total Cd content in the waste was determined by the decomposition of samples in aqua regia. The $\mathrm{Cd}$ concentration in post-extraction solutions was determined by the AAS method. On the basis of the obtained results, it was found that prolonged contact with water causes leaching (washing out) of significant amounts (5.6-11.8\% of the total content) of the element from the tested fresh waste. Prolonged contact with water, together with the influence of other atmospheric factors (temperature changes, sunshine, wind), has a negative influence on $\mathrm{Cd}$ stability in the examined waste, causing the release of significant amounts of that element into the surroundings, which may pose a threat to the environment.
\end{abstract}

\section{Introduction}

Stricter regulations regarding municipal waste storage [1] caused the necessity to look for alternative ways of managing this type of waste. One of the methods of waste disposal is its incineration in municipal waste thermal treatment plants (WTTP) [2]. During waste combustion in appropriate, controlled conditions, the volume is reduced and waste is solidified [3, 4]. In modern plants, part of the energy generated during combustion is converted into heat and electrical energy used for heating water or dwellings [3,5].

At the same time, apart from the advantages of thermal waste transformation, there are also disadvantages of this method. This waste management technology is not a waste-free method. As a result of municipal waste incineration, slags (as the main waste generated during combustion), dust, ashes and scrap are formed. Slags have the greatest development potential, for which storage was supposed to be the final destination until they find an appropriate economic use. Currently, research is ongoing regarding the management of this waste as aggregate for road embankments $[4,5]$.

\footnotetext{
"Corresponding author: beata.kosa@wp.pl
} 
However, in order for the waste to be managed - whether through landfill or aggregate it is necessary to examine them physically and chemically. Due to the variable nature of the incinerated waste, such parameters as chemical composition, mineral oil content and total organic carbon content [6] are examined, which requires repeating the tests at time intervals. One of the most important studies is to determine the stability of certain elements that may pose a threat to the life and/or health of organisms if they enter the environment in higher concentrations.

Cadmium was selected, as one of the most mobile elements, to investigate the stability of the chemical composition of slags from municipal waste incineration plants. This element occurs in all environmental components in different concentrations [7-9]. Cd compounds are easily liberated in aeration processes and then bound by clay minerals, iron hydroxides and organic substances, so that $\mathrm{Cd}$ compounds can be easily absorbed by plants and enter the animal and human food chain. Excess cadmium in plants is the result of its easy uptake by the root system and aboveground parts. It may be responsible for chlorotic and brown spots on leaf blades, redness of veins, twisting of leaves, as well as thickening and shortening of roots $[7,8]$. The effect of excess cadmium in plants is also associated with disturbances of photosynthesis, and transpiration and transformation of nitrogenous compounds, including DNA. In humans and animals, excessive concentration of Cd shows toxic effects. Cadmium excess in the organism can lead to serious disorders of the urinary and reproductive systems, as well as promote hypertensive disease and cancer. Excess of this element in the organism can also disturb the function of calcium metabolism $[7,8]$.

In Poland, until recently, there was only one plant for municipal waste thermal treatment [WTTP], located in Warsaw, and the literature on such waste research is quite limited. The subject of slag originating from WTTP was discussed by Kępys [5] and Zawada and Przerada[10]. The material from WTTP in Kraków has not been described so far, due to the short period of the plant's operation.

The following article contains the results of research on slags originating from the Thermal Treatment Plant of Municipal Waste in Kraków, including the following:

- determination of the total Cd content in fresh samples by digestion in aqua regia, after a stabilization period in the WTTP area, and in samples exposed to weather conditions (seasoning) for an additional 2-week period,

- determination of the Cd content washed out in the TVA test; for fresh and weathered samples,

- evaluation of Cd stability in slags originating from WTTP Kraków, based on the obtained results.

\section{Material and test methods}

The tests were carried out on samples of slags from the Waste Thermal Treatment Plant (WTTP) in Kraków. Due to the variability of waste subjected to incineration, slag samples were collected in three series: SP1 (March 2016), SP2 (September 2016), and SP3 (January 2017). Each series consisted of three types of fractions: fine (0-31 mm), thicker $(31-63 \mathrm{~mm})$, and a non-sort fraction containing the first two fractions and residues left after the combustion process (Fig. 1). Samples were taken from another plant collecting waste originating from an incineration plant, after two weeks of seasoning. Small parts of glass, metal elements and parts of building materials in the form of fragments of bricks and/or ceramic tiles were found in each sample. The largest amount of the above-mentioned parts was noticeable in the non-sort fraction. 

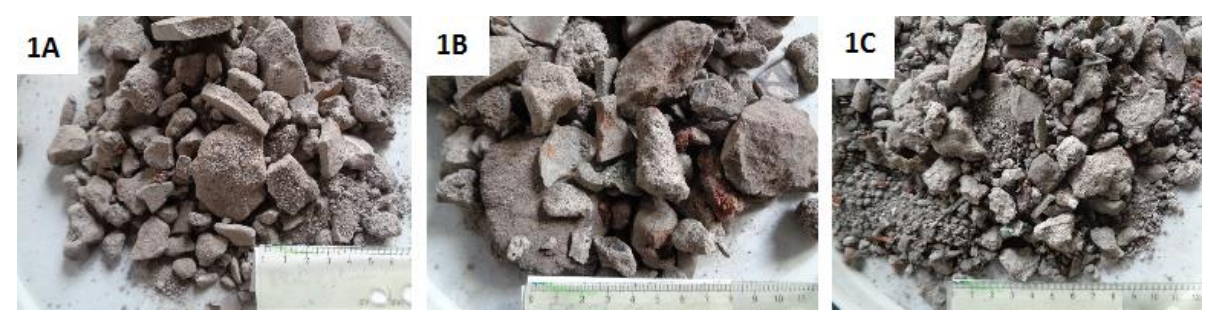

Fig. 1. Tested samples of slags; $1 \mathrm{~A}$ - fine fraction $(0-31 \mathrm{~mm}), 1 \mathrm{~B}$ - thicker fraction $(31-63 \mathrm{~mm})$, $1 \mathrm{C}-$ non-sort fraction. Source: author's photographies.

Each of the analyzed sample fractions was divided into two parts. The first part was dried under air-dry conditions. The remaining part was exposed to the influence of atmospheric factors, i.e. rainfall, sunshine and temperature changes for a period of 2 weeks, after which it was also dried in air-dry conditions. The dried fractions from both batches of the material were ground to a grain size $<0.5 \mathrm{~mm}$ by means of a laboratory mill, and submitted for further testing.

The stability of $\mathrm{Cd}$ in waste was assessed using the TVA test $[11,12]$. The purpose of this test is to simulate the natural conditions in which waste would be exposed to prolonged contact with water. The sample of waste is washed out twice with distilled water (saturated with $\mathrm{CO}_{2}$ ), each washing lasting 24 hours. The ratio of the weighed portion of waste to the used extractor was 1:10. The solutions were filtered off after 24 and 48 hours, and then Cd content was determined by means of the AAS method using a ThermoScientific iCE 300 spectrometer [13].

The total Cd content in the tested waste samples was determined by the decomposition of waste samples, of a weight in the range of $0.25-0.45 \mathrm{~g}$, in aqua regia, according to the standard [14]. The ratio of $\mathrm{HNO}_{3}$ and $\mathrm{HCl}$ acids was 1:3. Mineralization of samples proceeded in an open system at $130^{\circ} \mathrm{C}$. The $\mathrm{Cd}$ concentration in the obtained solutions was determined using the AAS method.

\section{Results}

\subsection{Total content}

The Cd content determined in samples that were not exposed to atmospheric conditions ranged from $3.57 \mathrm{mg} \cdot \mathrm{kg}^{-1}$ for the non-sort fraction of the SP1 series, to $8.56 \mathrm{mg} \cdot \mathrm{kg}^{-1}$ for the fine fraction of the same batch of SP1 samples (Table 1). For the other two series of sampling (SP2 and SP3), the lowest Cd contents were recorded for the non-sort fraction (5.16 and $5.61 \mathrm{mg} \cdot \mathrm{kg}^{-1}$ respectively), while the highest Cd contents (5.54 and $7.17 \mathrm{mg} \cdot \mathrm{kg}^{-1}$, respectively) were determined in the finest $0-31 \mathrm{~mm}$ fraction (Table 1 ).

In samples subjected to two weeks of seasoning under atmospheric conditions, $\mathrm{Cd}$ contents ranging between 2.00 and $6.56 \mathrm{mg} \cdot \mathrm{kg}^{-1}$ (Table 1) were found. The lowest content of the studied element (i.e. $2.00 \mathrm{mg} \cdot \mathrm{kg}^{-1}$ ) was determined for the non-sort fraction of SP1, and the highest Cd content $\left(6.56 \mathrm{mg} \cdot \mathrm{kg}^{-1}\right)$ was found for the sample of the finest fraction in the same series of SP1 (Table 1). For the remaining series the lowest amounts of $\mathrm{Cd}$ in the non-sort fraction were found as before, while the highest were found in the finest fraction.

The biggest differences in the Cd content of samples before and after seasoning under weather conditions were observed in the case of slags from the SP3 series, collected in the winter season - in January (Table 1). The lowest difference was found for the SP2 series samples taken in September 2016. These differences may be due to the fact that not all 
stabilization processes in the samples could be completed due to low temperatures during winter. The fact that the change in the $\mathrm{Cd}$ content is also associated with a change in the nature of the incinerated waste is also not without significance.

Table 1. Total content of $\mathrm{Cd}$ in slags before and after seasoning under weather conditions.

\begin{tabular}{|c|c|c|c|}
\hline \multirow{2}{*}{ Sample series } & \multirow{2}{*}{ Fraction [mm] } & \multicolumn{2}{|c|}{ Content of $\mathbf{C d}_{\boldsymbol{A R}}\left[\mathbf{m g} \cdot \mathbf{k g}^{-\mathbf{1}}\right]$} \\
\cline { 2 - 4 } & & before seasoning & After seasoning \\
\hline \multirow{2}{*}{ SP1 } & $0-31$ & 8.56 & 6.56 \\
\cline { 2 - 4 }$($ III 2016) & $31-63$ & 4.17 & 2.78 \\
\cline { 2 - 4 } & Non-sort & 3.57 & 2.00 \\
\hline \multirow{2}{*}{ SP2 } & $0-31$ & 5.54 & 3.62 \\
\cline { 2 - 4 }$(\mathrm{XI} 2016)$ & $31-63$ & 5.53 & 3.37 \\
\cline { 2 - 4 } & Non-sort & 5.16 & 3.34 \\
\hline \multirow{2}{*}{ SP3 } & $0-31$ & 7.17 & 4.79 \\
\cline { 2 - 4 }$(\mathrm{I} 2017)$ & $31-63$ & 6.39 & 3.99 \\
\cline { 2 - 4 } & Non-sort & 5.61 & 3.22 \\
\hline
\end{tabular}

\subsection{TVA test}

After the first stage of the TVA test ( 24 hours), washed-out Cd content determined from slag samples before exposure to atmospheric agents varied from $0.15 \mathrm{mg} \cdot \mathrm{kg}^{-1}$ for the SP1 non-sort fraction, to $0.30 \mathrm{mg} \cdot \mathrm{kg}^{-1}$ for the SP3 series non-sort fraction (Table 2). For the SP2 and SP3 series the lowest Cd quantities were recorded for fine fractions $(0-30 \mathrm{~mm})$, while for the SP1 series, the lowest values of the washed-out Cd were recorded for the non-sort fractions. The highest Cd contents were determined in the SP1 series for fine fractions, in the SP2 series for coarse fractions, and in the SP3 series for non-sort fractions (respectively, in $\mathrm{mg} \cdot \mathrm{kg}^{-1}: 0.20,0.22$ and 0.30$)$.

Table 2. Cd content leached by TVA test from slag samples before and after seasoning under weather conditions.

\begin{tabular}{|c|c|c|c|c|c|c|c|}
\hline \multirow{3}{*}{$\begin{array}{c}\text { Sample } \\
\text { series }\end{array}$} & \multirow{3}{*}{$\begin{array}{c}\text { Fraction } \\
{[\mathrm{mm}]}\end{array}$} & \multicolumn{6}{|c|}{ Content of $\mathrm{Cd}\left[\mathrm{mg} \cdot \mathrm{kg}^{-1}\right]$} \\
\hline & & \multicolumn{3}{|c|}{ Before seasoning } & \multicolumn{3}{|c|}{ After seasoning } \\
\hline & & $24 \mathrm{~h}$ & $48 \mathrm{~h}$ & $24 \mathrm{~h}+48 \mathrm{~h}$ & $24 \mathrm{~h}$ & $48 \mathrm{~h}$ & $24 \mathrm{~h}+48 \mathrm{~h}$ \\
\hline \multirow{3}{*}{$\begin{array}{c}\text { SP1 } \\
\text { (III } \\
2016 \text { ) }\end{array}$} & $0-31$ & 0.20 & 0.28 & 0.48 & 0.30 & 0.33 & 0.63 \\
\hline & $31-63$ & 0.16 & 0.26 & 0.42 & 0.26 & 0.28 & 0.54 \\
\hline & Non-sort & 0.15 & 0.27 & 0.42 & 0.23 & 0.31 & 0.54 \\
\hline \multirow{3}{*}{$\begin{array}{c}\text { SP2 } \\
\text { (XI } \\
2016) \\
\end{array}$} & $0-31$ & 0.18 & 0.35 & 0.53 & 0.27 & 0.34 & 0.61 \\
\hline & $31-63$ & 0.22 & 0.29 & 0.51 & 0.27 & 0.30 & 0.57 \\
\hline & Non-sort & 0.20 & 0.31 & 0.51 & 0.24 & 0.33 & 0.57 \\
\hline \multirow{3}{*}{$\begin{array}{c}\text { SP3 } \\
\text { (I 2017) }\end{array}$} & $0-31$ & 0.27 & 0.34 & 0.61 & 0.27 & 0.43 & 0.70 \\
\hline & $31-63$ & 0.28 & 0.28 & 0.56 & 0.29 & 0.33 & 0.62 \\
\hline & Non-sort & 0.30 & 0.26 & 0.56 & 0.31 & 0.32 & 0.63 \\
\hline
\end{tabular}

After the second stage of the test (lasting 48 hours), Cd content was found in the range from $0.26 \mathrm{mg} \cdot \mathrm{kg}^{-1}$ in samples of the thick/coarse fraction series SP1 and in the fraction of non-sort series SP3, up to $0.35 \mathrm{mg} \cdot \mathrm{kg}^{-1}$ for the sample of fine fraction SP2 series (Table 2). For this stage of the test the highest $\mathrm{Cd}$ concentrations were determined for the fine fraction for all series, while the lowest Cd content was found for the coarse fraction (SP1 and SP2 series) and for the non-sort fraction (SP3 series).

In total, for all samples of slag (before and after seasoning), the lowest amounts of Cd were leached from the coarse fraction and the non-sort one (for both fractions of all 
collected batches they were similar amounts), while the highest amount of Cd was leached from the fine fraction. (Table 2).

Compared to the total $\mathrm{Cd}$ content in slag before seasoning, and determined by means of sample digestion in aqua regia, the amount of leaching $\mathrm{Cd}$ after $48 \mathrm{~h}$ of test duration ranged from $5.6 \%$ (for the SP1 fine fractions) to $11.8 \%$ (for the SP1 series non-sort fraction) (Table 3 ). On the basis of the obtained data, there was no clear trend indicating which of the tested fractions is the most susceptible to cadmium leaching. The smallest differences regarding the amount of leached Cd between the prepared fractions were found for the SP2 series (9.2-9.9\%), and the biggest differences were found between the SP1 samples (5.6-11.8\%) (Table 3).

For samples of seasoned slags, in the first stage of the test (i.e. after 24h) the amount of leached Cd was between $0.23 \mathrm{mg} \cdot \mathrm{kg}^{-1}$ (SP1 series, non-sort fraction) and $0.31 \mathrm{mg} \cdot \mathrm{kg}^{-1}$ (also SP3 series, non-sort fraction). The highest concentrations of the studied element were obtained from the leaching of SP3 series non-sort fractions $\left(0.31 \mathrm{mg} \cdot \mathrm{kg}^{-1}\right)$, and SP1 series fine fractions $\left(0.30 \mathrm{mg} \cdot \mathrm{kg}^{-1}\right)$ and SP2 series $\left(0.27 \mathrm{mg} \cdot \mathrm{kg}^{-1}\right)$. The lowest concentrations of Cd were determined for the SP1 and SP2 series, for non-sort fraction $(0.23$ and $0.24 \mathrm{mg} \cdot \mathrm{kg}^{-1}$, respectively) and for the SP3 series in the fine fraction $\left(0.27 \mathrm{mg} \cdot \mathrm{kg}^{-1}\right)$.

Table 3. Cd content leached by TVA test $(24 \mathrm{~h}+48 \mathrm{~h})$ as a percent of total content.

\begin{tabular}{|c|c|c|c|}
\hline \multirow{2}{*}{ Sample series } & \multirow{2}{*}{ Fraction [mm] } & $\begin{array}{c}\text { Content of Cd leached by TVA test } \mathbf{2 4} \mathbf{h}+\mathbf{4 8} \mathbf{~ h} \text { ) as } \\
\mathbf{a} \% \text { of total content }\end{array}$ \\
\cline { 2 - 4 } & & Before seasoning & After seasoning \\
\cline { 2 - 4 } \multirow{2}{*}{ SP1 } & $0-31$ & 5.6 & 9.6 \\
\cline { 2 - 4 }$($ III 2016) & $31-63$ & 10.1 & 19.4 \\
\cline { 2 - 4 } & Non-sort & 11.8 & 27.0 \\
\hline \multirow{2}{*}{ SP2 } & $0-31$ & 9.6 & 16.9 \\
\cline { 2 - 4 }$(\mathrm{XI} 2016)$ & $31-63$ & 9.9 & 17.0 \\
\cline { 2 - 4 } & Non-sort & 9.2 & 16.9 \\
\hline \multirow{2}{*}{ SP3 } & $0-31$ & 10.9 & 21.7 \\
\cline { 2 - 4 }$(\mathrm{I} 2017)$ & $31-63$ & 8.8 & 15.5 \\
\cline { 2 - 4 } & Non-sort & 7.8 & 13.3 \\
\hline
\end{tabular}

After the second stage of the test (i.e. after $48 \mathrm{~h}$ ), from the seasoned slags the leached Cd concentration was between $0.28 \mathrm{mg} \cdot \mathrm{kg}^{-1}$ (coarse fraction SP1 series) and $0.43 \mathrm{mg} \cdot \mathrm{kg}^{-1}$ (fine fraction of SP3 series). The lowest amounts of the studied element were leached from the coarse fraction of the SP1 series $\left(0.28 \mathrm{mg} \cdot \mathrm{kg}^{-1}\right)$, the SP2 series also from the coarse fraction $\left(0.30 \mathrm{mg} \cdot \mathrm{kg}^{-1}\right)$, from the non-sort fraction of the SP3 series $\left(0.43 \mathrm{mg} \cdot \mathrm{kg}^{-1}\right)$ (Table 2). The highest amount of $\mathrm{Cd}$ leached from all series was from the fine fraction $(0.33,0.34$ and $0.43 \mathrm{mg} \cdot \mathrm{kg}^{-1}$, respectively) (Table 2 ).

In total, after both TVA stages of the TVA test, the largest amounts of Cd were leached from the fine fractions of all extracted slag series, while the smallest amounts were leached from the thick fraction and non-sort fraction.

When comparing the samples exposed to atmospheric factors with the so-called unseasoned samples, it should be stated that larger amounts of $\mathrm{Cd}$ were removed from the samples subjected to seasoning (10 to 30\%) for all separated fractions and all tested series (Table 2).

When comparing the results of Cd leaching from slags subjected to seasoning after $48 \mathrm{~h}$ hours in relation to their total $\mathrm{Cd}_{\mathrm{AR}}$ content, it should be stated that this amount ranged from $9.6 \%$ (for the SP1 fine fractions) to $27.0 \%$ (for the SP1 series of non-sort fraction) (Table 3). 


\subsection{Evaluation of $\mathrm{Cd}$ leaching from slags due to atmospheric factors' influence}

The evaluation of the Cd mobility in slags from the municipal waste incineration plant was made on the basis of a comparison of the results of the determination of the analyzed element total content in unseasoned samples and in samples subjected to a two-week exposure to atmospheric conditions. The difference in total content was converted into percentages, considering the content determined in unseasoned samples as 100 .

Based on the analysis of the change in total $\mathrm{Cd}_{\mathrm{AR}}$ content in the seasoned samples compared to the non-seasoned ones, it can be observed that the influence of atmospheric factors causes $\mathrm{Cd}$ to be easily washed-out from the tested waste (Table 4). The smallest amounts of the element were leached from a series of samples taken in March 2016 (23-44\%), with the highest quantities from a series of samples taken in January 2017 (33-43\%). On average, in the first analyzed slag series $34 \% \mathrm{Cd}$ was lost during the seasoning process, and in the second SP2 series slightly more than $36 \%$. The biggest change of Cd content in slags, about 38\%, was recorded for the third SP3 series (Table 4). Therefore, the biggest changes were observed in the winter month, slightly lower in the autumn month, and the lowest in the spring month.

Table 4. Content of $\mathrm{Cd}$ leached from tested samples during the seasoning.

\begin{tabular}{|c|c|c|}
\hline Sample series & Fraction [mm] & $\begin{array}{c}\text { Content of Cd leached from slags before } \\
\text { seasoning Cd } \boldsymbol{A R} \text { [\%] }\end{array}$ \\
\hline \multirow{2}{*}{ SP1 } & $0-31$ & 23 \\
\cline { 2 - 3 }$($ III 2016$)$ & $31-63$ & 33 \\
\cline { 2 - 3 } & Non-sort & 44 \\
\hline \multirow{2}{*}{ SP2 } & $0-31$ & 35 \\
\cline { 2 - 3 }$($ XI 2016$)$ & $31-63$ & 39 \\
\cline { 2 - 3 } & Non-sort & 35 \\
\hline \multirow{2}{*}{ SP3 } & $0-31$ & 33 \\
\cline { 2 - 3 }$(\mathrm{I} 2017)$ & $31-63$ & 38 \\
\cline { 2 - 3 } & Non-sort & 43 \\
\hline
\end{tabular}

When analyzing change in $\mathrm{Cd}$ content during seasoning from the perspective of individual fractions, it should be noted that the smallest change is observed in the small fraction $(0-30 \mathrm{~mm})$. For all the slags of this fraction investigated, an average reduction of $\mathrm{Cd}$ content by $30 \%$ was calculated. For the thicker slag fraction $(31-63 \mathrm{~mm})$ there was a $37 \%$ reduction. The largest metal leaching process, during seasoning, was observed in the case of the non-sort fraction, for which there was a $41 \%$ decrease in $\mathrm{Cd}$ content between slags before seasoning and after seasoning.

A two-stage TVA test carried out on waste samples showed that cadmium in nonseasoned wastes was more mobile during prolonged contact with $\mathrm{CO}_{2}$-saturated water (Table 2). For a series of SP1 and SP2 waste samples, the amount of Cd leaching after 48 hours in relation to the quantity leached after 24 hours differed by $60 \%$, but for the SP3 series only by $4 \%$. Analyzing the change in the amount of eluted $\mathrm{Cd}$ from individual fractions, it should be noted that the biggest difference $(53 \%)$ was recorded for the finest fraction, and the lowest one for the thick fraction (31\%).

For seasoned wastes, the difference between the amount of leached $\mathrm{Cd}$ for each series was significantly smaller, and was successively $17 \%$ for the SP1 series, and $25 \%$ for the SP2 and SP3 series. Similarly to the case of un-seasoned slags, the largest differences were found for the smallest fraction (32\%), and the smallest for the thicker fraction (11\%).

This means that cadmium in wastes that are exposed to atmospheric conditions and to prolonged contact with water is still mobile and can be washed out. Even if the washed-out 
Cd will be on a similar level it may pose a threat to the environment through accumulation in the environment, absorbed by plants and enter the animal and human food chain.

\section{Conclusions}

Tests carried out on samples of fresh slags and a 2-week period of exposure to atmospheric conditions showed how the release of Cd contained in waste from WTTP changes. Studies have shown that:

1. The Cd content in fresh waste depends on the sampling time. The lowest total $\mathrm{Cd}$ content (depending on the fraction of the tested material ranging from 3.57 to $8.56 \mathrm{mg} \cdot \mathrm{kg}^{-1}$ ) was found in an SP1 series of samples taken in March 2016, while the highest Cd content (analogically as previously from 5.61 to $7.17 \mathrm{mg} \cdot \mathrm{kg}^{-1}$ ) was determined in samples of the SP3 series taken in January 2017.

2. After two weeks of atmospheric conditions exposure on the analyzed waste samples, Cd contents in the tested samples were significantly lower (ranging from 2.00 to $6.56 \mathrm{mg} \cdot \mathrm{kg}^{-1}$ ). This indicates the significant influence of atmospheric factors on the mobility of $\mathrm{Cd}$ in slags from municipal waste incineration.

3. The fine fraction $(0-31 \mathrm{~mm})$ turned out to be the most susceptible to leaching $\mathrm{Cd}$ from fresh and seasoned waste in all series of samples. For the remaining fractions, thick and non-sort, the total values of the eluted $\mathrm{Cd}$ remain at a similar level within the collected series.

4. The Cd washing-out depends on contact time with the extraction agent. Prolonged contact with $\mathrm{CO}_{2}$-saturated water increases $\mathrm{Cd}$ elution from waste. For unseasoned samples, the amount of extracted element increased on average by $41 \%$ between 24 and 48 hours' leaching. For samples exposed to atmospheric conditions, a significantly lower increase (of about $22 \%$ ) in leaching of the $\mathrm{Cd}$ element was observed for all fractions and series.

5. The amount of Cd leaching from the tested slag samples by TVA is quite significant, ranging from 5.6 to $11.8 \%$ of the total content for fresh samples, and 9.6 to $27.0 \%$ for seasoned ones.

6. The influence of atmospheric factors on the tested waste samples stimulates $\mathrm{Cd}$ mobility, increasing it by $38 \%$ on average. The amount of eluted element can have a negative impact on the environment.

The research has been funded by AGH University of Science and Technology GGiOŚ Dean's Grant no. 15.11 .140 .864 .

\section{References}

1. Dyrektywa RE 1999/31/WE z dn. 26.04.1999 r. w sprawie składowania odpadów

2. M. Nowak, S. Stelmach, Archiwum Gospodarki Odpadami i Ochrony Środowiska, 4, 16, 23-32 (2014)

3. J. Toruński, Zeszyty Naukowe Uniwersytetu Przyrodniczo-Humanistycznego w Siedlcach, 14, 87, 31-47 (2010)

4. K. Jankowski, A. Kaczorek, B. Wiśniewska-Kadżajan, E. Malinowska, H. Wyrębek, Zeszyty Naukowe Uniwersytetu Przyrodniczo-Humanistycznego w Siedlcach, 29, 102, 9-19 (2014)

5. W. Kępys, Gospod. Surowcami Min. 24, 3/3, 149-156 (2008) 
6. Dz. U. 2015 poz. 1277 - Rozporządzenie Ministra Gospodarki z dn. 16.07.2015 r., w sprawie dopuszczenia odpadów do składowania na składowiskach (2015)

7. A. Kabata-Pendias, H. Pendias, Biogeochemia pierwiastków śladowych (Wydawnictwo Naukowe PWN, Warszawa, 1999)

8. P. Ostrowska, Gospod. Surowcami Min. 24, 3/3, 255-260 (2008)

9. K. Nowińska, Z. Adamczyk, Górnictwo i Geologia, 8, 1, 77-87 (2013)

10. A. Zawada, I. Przerada, Szkło i Ceramika, 1, 62, 36-41 (2011)

11. M. Woźniak, M. Żygadło, Regionalny Monitoring Środowiska Przyrodniczego, 3, 117-122 (2002)

12. M. Woźniak, M. Żygadło, J. Latosińska, Ochr. Sr. 1, 26, 25-31 (2004)

13. PN-ISO 8288:2002 - Oznaczanie Co, Ni, Cu, Zn, Cd i Pb-Metoda AAS z atomizacja w ptomieniu (2002)

14. PN-EN 13657:2006 - Charakterystyka odpadów - Roztwarzanie do dalszego oznaczania części pierwiastków rozpuszczalnych w wodzie królewskiej (2006) 